\title{
Administration of Clinoptilolite to Broiler Chickens During Growth and Its Effect on the Growth Rate and Bone Metabolism Indicators
}

\author{
E. STRAKOVÁ ${ }^{1}$, R. POSPÍŠIL ${ }^{2}$, P. SUCHÝ ${ }^{1}$, L. STEINHAUSER ${ }^{1}$, I. HERZIG $^{1}$
}

${ }^{1}$ Department of Nutrition, Animal Husbandry and Animal Hygiene, Faculty of Veterinary Hygiene and Ecology, University of Veterinary and Pharmaceutical Science, Brno, Czech Republic

${ }^{2}$ Department of Financial Law and Economics, Faculty of Law, Palacký University Olomouc,

Czech Republic

Received November 12, 2007

Accepted February 14, 2008

\begin{abstract}
Straková E., R. Pospíšil, P. Suchý, L. Steinhauser, I. Herzig: Administration of Clinoptilolite to Broiler Chickens During Growth and Its Effect on the Growth Rate and Bone Metabolism Indicators. Acta Vet Brno 2008, 77: 199-207.

The growth rate and bone metabolism indicators were monitored in broiler chickens receiving the feed supplemented with clinoptilolite. One-day-old broiler chickens ROSS 308 were divided into control (C) and experimental (E) groups with 100 males and 100 females per group. The chickens received the complete feed mixture BR1 from 1 to 10 days of age, followed by the feed mixture BR2 until the age of 30 days, and the feed mixture BR3 until the end of the experiment (40 days). The feed mixtures of the experimental group were supplemented with clinoptilolite (commercial additive ZeoFeed) at a level of $0.5 \%$ (BR1), 1.5\% (BR2) and 2.5\% (BR3), replacing the corresponding portion of wheat. Feed mixtures and drinking water were provided ad libitum. The live weight of broiler chickens in both the control and experimental group increased steadily during the experiment. At the end of the experiment, live weights of experimental females $(2,416 \mathrm{~g})$ and males $(2,829 \mathrm{~g})$ were higher than those of control females $(2,345 \mathrm{~g})$ and males $(2,694 \mathrm{~g})$ by $3 \%$ and $5 \%$, respectively. Significant differences in the live weight between groups were found from the age of 30 days $(P \leq 0.05$ and $P \leq 0.01)$. At the age of 40 days, the chickens were slaughtered and the femur and tibiotarsus of the right leg were analysed for the content of dry matter, ash, calcium, phosphorus and magnesium. The ash content in dry matter ranged from 53.0 to $54.1 \%$ in group $\mathrm{C}$ and from 51.7 to $53.2 \%$ in group $\mathrm{E}$. The $\mathrm{Ca}$ and $\mathrm{P}$ contents in dry matter in group $\mathrm{E}$ were lower than those in group $\mathrm{C}$, except for $\mathrm{Ca}$ and $\mathrm{P}$ in the male tibiotarsus. In both groups, regardless of sex, the ash content was higher in the tibiotarsus than in the femur. Since fat levels in bones of the experimental group were increased (females by $19.5 \%$ in the femur and $21.3 \%$ in the tibiotarsus; males by $22.0 \%$ in the femur and $26.3 \%$ in the tibiotarsus), which could affect the values obtained, ash, calcium, phosphorus and magnesium were determined in the fat-free dry matter. The trends found in the originally determined dry matter were maintained, i.e. lower levels of ash, $\mathrm{Ca}$, and $\mathrm{P}$ in the experimental group, except for male $\mathrm{Ca}$ in both kinds of bones. The corresponding levels in the fat-free dry matter were relatively higher as compared to the original dry matter. The results of the study showed that up to $2.5 \%$ of clinoptilolite in the diet had no adverse effect on performance and bone metabolism indicators of growing broiler chickens. Thus, it can be used as a suitable feed additive to broiler diets due to its positive effect on nutrient utilization, mechanism of digestion and pollutant elimination in connection with food safety issues.
\end{abstract}

Zeofeed, weight of chickens, bone tissue, ash, calcium, phosphorus, magnesium

Zeolites represent a large and very diverse group of minerals such as water-silicates that are characterized by three-dimensional structure and belong to the class of aluminosilicates from a chemical point of view. Their structure is based on a three-dimensional skeleton consisting of $\mathrm{SiO}_{4}$ and $\mathrm{AlO}_{4}$ tetrahedrons that form interconnected channels and cavities containing weakly bound (quite mobile) water molecules and cations of alkali metals $(\mathrm{Na}, \mathrm{K}, \mathrm{Li}, \mathrm{Cs})$ and alkaline earth metals $(\mathrm{Ca}, \mathrm{Mg}, \mathrm{Ba}, \mathrm{Sr})$, which compensate for the unsaturated negative valence of $\mathrm{AlO}_{4}$. Phosphorus substituting silicon and beryllium or 
iron substituting aluminium may contribute to the structure of the skeleton. Zeolites have a characteristic crystal structure. Thanks to their specific physicochemical properties, they have a considerable potential to be used in the area of animal production.

More than 40 kinds of zeolites have been described so far. Natural as well as synthetic zeolites are being used successfully as feed supplements, with clinoptilolite $\left[(\mathrm{NaK})_{6}\right.$ $\left.\left(\mathrm{Al}_{6} \mathrm{Si}_{30} \mathrm{O}_{72}\right) \cdot 20 \mathrm{H}_{2} \mathrm{O}\right]$ and mordenite $\left[\left(\mathrm{CaNa}_{2} \mathrm{~K}_{2}\right)\left(\mathrm{Al}_{2} \mathrm{Si}_{10} \mathrm{O}_{24}\right) \cdot 7 \mathrm{H}_{2} \mathrm{O}\right]$ that are used most frequently. Zeolites received with feed are involved in a number of biochemical processes through ion exchange, adsorption, catalysis, and dehydration-rehydration properties (Mumpton 1999).

The effectiveness of zeolites was verified and confirmed in a number of areas, for example improved performance indicators. The administration of clinoptilolite as a feed supplement enhanced feed utilization (Olver 1997). Furthermore, zeolites have a beneficial effect on the mechanism of digestion, participate in the elimination of heavy metals (Tepe et al. 2004) and radioactive elements, and repair the metabolic defects of the skeleton (Papaioannou et al. 2005).

Over the last ten years, clinoptilolites have been used as adsorbents to bind a wide range of mycotoxins, thus reducing their toxic effects (Harvey et al. 1993; Skalická and Makoová 1999; Skalická et al. 2000; Parlat et al. 1999; Ortatatli and Oguz 2001; Rizzi et al. 2003). In in vitro experiments, sodium bentonite showed a high sorption capacity for aflatoxin B1 and decreased the overall content of aflatoxins in growing broilers (Rosa et al. 2001). The lower mortality and improved weight gains in piglets have been reported by Papaioannou et al. (2002; 2004).

Clinoptilolites were shown to be highly effective with regard to the metabolic utilization of nitrogen in poultry and pigs. This may indicate that one may decrease the concentration of nitrogen-containing substances in a feeding dose without affecting performance of animals. One of the significant features of clinoptilolites is that they are able to bind ammonia, which reduces the release of nitrogen via excrements and thus limits the concentration of nitrogen in animal houses and the environment (Amon et al. 1997; Meisinger et al. 2001; Melenova et al. 2003).

Data on how to affect bone tissue composition in birds (deposition of $\mathrm{Ca}, \mathrm{P}$ and $\mathrm{Mg}$ ) after the administration of clinoptilolites is published only sporadically in literature (Leach et al. 1990; Papaioannou et al. 2005). Grosicki and Kowalski (2003), Grosicki et al. (2004), and Grosicki and Rachubik (2005) studied the effect of bentonite on the kinetics of iron, calcium, and selenium in rats. The absorption of selenium and calcium in organs was decreased while the absorption of iron increased. The relationship between natural/ synthetic zeolites and tibial dyschondroplasia in chickens was investigated by Ledwaba and Roberson (2003), Edwards (1988), Ballard and Edwards (1988), and Watkins and Southern (1991).

The main aim of the presented work was to investigate the effect of clinoptilotite as a feed supplement on the selected production and bone metabolism indicators in broilers during their growth at defined experimental conditions.

\section{Materials and Methods}

The experiment was performed in the accredited experimental enclosure of the Department of Nutrition, Animal Husbandry and Animal Hygiene, Faculty of Veterinary Hygiene and Ecology, University of Veterinary and Pharmaceutical Sciences, Brno. A total of 400 sexed one-day-old chickens (hybrid ROSS 308) were selected and divided into two groups: control group (C) and experimental group (E), each consisting of 100 male chickens and 100 female chickens. Chickens were reared individually in aviaries equipped with an automatic system of watering and manual feeding, in a setting with controlled light and temperature regimen. The experiment was finished when the chickens reached the age of 40 days.

Chickens received the complete feed mixture BR1 from the start of the experiment until Day 10, followed by the feed mixture BR2 from Day 11 to Day 30 and the feed mixture BR3 from Day 31 to Day 40. All feed mixtures contained the same components; the only difference was that the mixtures designed for the experimental group 
were supplemented with $0.5 \%$ (BR 1), $1.5 \%$ (BR 2), and 2.5\% (BR 3) of clinoptilolite (commercial additive ZeoFeed) to replace respective portions of wheat. Feed mixtures and drinking water were provided ad libitum. The levels of basic components and nutrient composition of feed mixtures are provided in Table 1.

Table 1. Composition of feed mixtures (\%) and the content of basic nutrients $\left(\mathrm{g} \cdot \mathrm{kg}^{-1}\right)$

\begin{tabular}{|l|c|c|c|}
\hline & C BR1 & C BR2 & C BR3 \\
\hline Wheat & 24.34 & 23.55 & 19.23 \\
\hline Maize & 35.0 & 40.0 & 40.0 \\
\hline Soy extracted meal & 24.0 & 18.5 & 20.0 \\
\hline Fish meal & 10.0 & 10.0 & 5.0 \\
\hline Wheat meal & - & - & 5.0 \\
\hline Soy oil & 1.5 & 3.3 & 5.43 \\
\hline Monocalcium phosphate & 0.37 & 0.19 & 0.51 \\
\hline Ground lime & 0.9 & 0.75 & 1.11 \\
\hline DL methionine & 0.23 & 0.17 & 0.18 \\
\hline NP nove & 0.9 & 0.9 & 0.8 \\
\hline Biolys 65 & 0.16 & 0.06 & 0.02 \\
\hline Vitex Q & 2.5 & 2.5 & 2.5 \\
\hline Feeding salt & 0.1 & 0.08 & 0.22 \\
\hline \multicolumn{4}{|l|}{} \\
\hline Dry matter & 883.6 & 885.6 & 887.1 \\
\hline N-substances & 242.8 & 220.1 & 199.8 \\
\hline Fat & 45.5 & 64.6 & 82.7 \\
\hline Fibre & 26.1 & 24.9 & 26.1 \\
\hline Ash & 56.6 & 50.6 & 51.9 \\
\hline ME MJ'kg-1 & 12.6 & 13.29 & 13.5 \\
\hline
\end{tabular}

$0.5 \%(\mathrm{BR} 1) ; 1.5 \%(\mathrm{BR} 2)$ and $2.5 \%(\mathrm{BR} 3)$ of wheat in the mixtures designed for Group E was substituted with clinoptilolite (commercial additive Zeofeed)
Active substance specification

The feed additive ZeoFeed which was used in this experiment contains at least $80 \%$ of clinoptilolite as an active substance, at a moisture level of max. $6 \%$. It also contains $62 \%$ of $\mathrm{SiO}_{2}, 14 \%$ of $\mathrm{Al}_{2} \mathrm{O}_{3}, 2.3 \%$ of $\mathrm{Fe}_{2} \mathrm{O}_{3}$ and $5.5 \%$ of $\mathrm{CaO}$. Particle size varies in a range of $0.2-0.5 \mathrm{~mm}$.

\section{Live weight determination}

The weight of the chickens was determined on Days 1, 11, 20, 30, and 40 of the chickens' age. The weight was determined at the accuracy of one tenth of a gram, at the same time of day and at the same order of groups. Together with live weight determination, the consumption of feed mixtures was also estimated.

\section{Chemical composition of bones}

At the end of the experiment, the chickens were slaughtered. The femur and the tibiotarsus of the right leg in 60 control and 60 experimental chickens were collected and analysed for dry matter, fat, ash, calcium in ash, phosphorus, and magnesium in the original mass, absolute matter, and fatfree dry matter (Anonymous - AOAC 2001).

Health

The health condition of broiler chickens was monitored throughout the experiment, with no clinical symptoms of any disease being recorded. In the course of the experiment, 5 female and 8 male chickens died in the control group, and 4 female and 7 male chickens (yolk peritonitis, cardiac failure) died in the experimental group.

\section{Statistical evaluation}

ANOVA was used to process the data with homogeneous dispersion followed by Tukey-HSD test to perform multiple comparisons in order to find the pairs of groups with significant differences. The Kruskal-Wallis ANOVA method was used for the data with non-homogeneous dispersion, followed by non-parametric rank test (Tukeytype multiple comparisons).

\section{Results}

The administration of clinoptilolite $(0.5 ; 1.5$, and $2.5 \%$ of the commercial additive ZeoFeed) in the feed mixtures for the chickens in the experimental group (Group E) was positively reflected in performance indicators. Chickens in both groups showed steady weight gains throughout the whole experiment but male and female chickens in the experimental group exhibited higher weights from Day 20 or Day 30, respectively. The corresponding differences were significant on Day 30 of the chickens' age $(P \leq 0.05)$, the weight of chickens in the experimental group at the end of the experiment was significantly higher $(P \leq 0.01)(\hat{\partial} 2,829 \mathrm{~g}$ and $q 2,416 \mathrm{~g})$, as compared to that in the control group ( $\hat{\sigma}$ $2,694 \mathrm{~g}$ and $92,345 \mathrm{~g}$ ) (Table 2).

Chickens were slaughtered at the end of the experiment, i.e. on Day 40. The femur and the tibiotarsus were collected and analysed for the contents of dry matter, fat, ash, $\mathrm{Ca}, \mathrm{P}$ and $\mathrm{Mg}$ (Table 3). The level of ash in dry matter in bone tissue from the femur and the 
Table 2. Live weight of broiler chickens in the course of fattening (g)

\begin{tabular}{|c|c|c|c|c|c|c|c|c|}
\hline Age (days) & \multicolumn{4}{|c|}{ Female chickens } & \multicolumn{4}{|c|}{ Male chickens } \\
\hline Group & $\mathrm{n}$ & Weight & & Index & $\mathrm{n}$ & Weight & & Index \\
\hline $\mathrm{C}$ & & $\bar{x}$ & $\pm \mathrm{SD}$ & $\%$ & & $\bar{x}$ & $\pm \mathrm{SD}$ & $\%$ \\
\hline 1 & 100 & 41 & 0.3 & 100 & 100 & 45 & 0.4 & 100 \\
\hline 11 & 98 & 244 & 3.0 & 100 & 100 & 255 & 3.3 & 100 \\
\hline 20 & 98 & 743 & 9.3 & 100 & 98 & 811 & 9.9 & 100 \\
\hline 30 & 97 & $1345^{\mathrm{a}}$ & 15.4 & 100 & 96 & $1509^{a}$ & 16.0 & 100 \\
\hline 40 & 95 & $2345^{\mathrm{A}}$ & 23.9 & 100 & 92 & $2694^{\mathrm{A}}$ & 32.6 & 100 \\
\hline Group & $\mathrm{n}$ & Weight & & Index & $n$ & Weight & & Indey \\
\hline$E$ & & $\bar{x}$ & $\pm \mathrm{SD}$ & $\%$ & & $\bar{x}$ & $\pm \mathrm{SD}$ & $\%$ \\
\hline 1 & 100 & 41 & 0.3 & 100 & 100 & 45 & 0.3 & 100 \\
\hline 11 & 100 & 238 & 2.7 & 97.5 & 99 & 252 & 2.8 & 98.8 \\
\hline 20 & 99 & 756 & 7.3 & 101.7 & 97 & 811 & 8.4 & 100 \\
\hline 30 & 97 & $1439^{b}$ & 11.1 & 107.0 & 95 & $1589^{\mathrm{b}}$ & 16.4 & 105.3 \\
\hline 40 & 96 & $2416^{\mathrm{B}}$ & 24.0 & 103.0 & 93 & $2829^{\mathrm{B}}$ & 30.1 & 105.0 \\
\hline
\end{tabular}

$\mathrm{n}$ - number of chickens, $\bar{x}$ - arithmetic means, $\mathrm{SD}$ - standard deviation, $P$ - level of significance, ab $P \leq 0.05$, AB $P \leq 0.01$

tibiotarsus varied in the range of $53.0-54.1 \%$ in the control group and $51.7-53.2 \%$ in the experimental group, which was non-significantly less as compared to the control group. The level of ash in dry matter was higher in the tibiotarsus as compared to that in the femur, in both groups, irrespective of sex. The level of $\mathrm{Ca}$ and $\mathrm{P}$ in dry matter in the experimental group was lower than in the control group, the only exception were the levels of $\mathrm{Ca}$ in the tibiotarsus in male chickens. The level of $\mathrm{Ca}$ in ash in the control group was $20.6 \%$ in the femur and $21.5 \%$ in the tibiotarsus in female chickens, while in male chickens lower values of $19.9 \%$ and $19.7 \%$, respectively, were found. Similar levels were found in the experimental group of female (19.7\% and $19.6 \%)$ and male chickens $(19.8 \%$ and $20.0 \%)$. The levels of phosphorus were similar, ranging from $9.06 \%$ to $10.4 \%$ in the control group, and from $7.92 \%$ to $9.55 \%$ in the experimental group, which is slightly less, as compared to the control group. The levels of magnesium did not differ between both groups and sexes. No significant differences were found.

Table 3. Levels of ash, Ca, P, and Mg in Groups C and E in original dry matter ( $\mathrm{g}$ )

\begin{tabular}{|c|c|c|c|c|c|c|c|c|}
\hline \multirow{2}{*}{$\begin{array}{c}\text { Group } \\
\mathrm{C}\end{array}$} & \multicolumn{4}{|c|}{ Female chickens } & \multicolumn{4}{|c|}{ Male chickens } \\
\hline & Femur & Index $\%$ & Tibiotarsus & Index $\%$ & Femur & Index $\%$ & Tibiotarsus & Index $\%$ \\
\hline & $(n=30)$ & & $(\mathrm{n}=30)$ & & $(\mathrm{n}=30)$ & & $(n=30)$ & \\
\hline Dry matter & $899.9 \pm 2.02$ & 100 & $894.1 \pm 2.68$ & 100 & $901.5 \pm 3.80$ & 100 & $907.3 \pm 1.81$ & 100 \\
\hline Ash & $477.0 \pm 12.5$ & 53.0 & $483.8 \pm 9.44$ & 54.1 & $479.4 \pm 12.5$ & 53.2 & $485.3 \pm 12.0$ & 53.5 \\
\hline $\mathrm{Ca}$ & $185.6 \pm 6.37$ & 20.6 & $192.1 \pm 6.70$ & 21.5 & $179.7 \pm 7.56$ & 19.9 & $178.6 \pm 10.5$ & 19.7 \\
\hline $\mathrm{P}$ & $93.5 \pm 7.56$ & 10.4 & $92.0 \pm 4.41$ & 10.3 & $81.7 \pm 3.49$ & 9.06 & $84.1 \pm 5.46$ & 9.27 \\
\hline $\mathrm{Mg}$ & $2.12 \pm 0.20$ & 0.24 & $2.17 \pm 0.21$ & 0.24 & $2.11 \pm 0.19$ & 0.23 & $2.10 \pm 0.22$ & 0.23 \\
\hline$E$ & $(\mathrm{n}=30)$ & & $(\mathrm{n}=30)$ & & $(\mathrm{n}=30)$ & & $(\mathrm{n}=30)$ & \\
\hline Dry matter & $902.6 \pm 2.18$ & 100 & $897.1 \pm 2.34$ & 100 & $900.4 \pm 2.88$ & 100 & $898.8 \pm 4.48$ & 100 \\
\hline Ash & $466.8 \pm 10.3$ & 51.7 & $472.9 \pm 8.08$ & 52.7 & $465.4 \pm 11.3$ & 51.7 & $478.4 \pm 9.11$ & 53.2 \\
\hline $\mathrm{Ca}$ & $177.8 \pm 9.95$ & 19.7 & $175.7 \pm 16.0$ & 19.6 & $178.6 \pm 8.13$ & 19.8 & $180.0 \pm 7.04$ & 20.0 \\
\hline $\mathrm{P}$ & $86.2 \pm 5.30$ & 9.55 & $76.2 \pm 4.81$ & 8.49 & $71.3 \pm 5.42$ & 7.92 & $80.9 \pm 3.94$ & 9.00 \\
\hline $\mathrm{Mg}$ & $2.29 \pm 0.17$ & 0.25 & $2.17 \pm 0.17$ & 0.24 & $2.27 \pm 0.19$ & 0.25 & $2.05 \pm 0.18$ & 0.23 \\
\hline
\end{tabular}


As the content of fat in bones increased by $19.5 \%$ in the femur and by $21.3 \%$ in the tibiotarsus in experimental female chickens, and by $22.0 \%$ in the femur and $26.3 \%$ in the tibiotarsus in experimental male chickens (Table 4), which was supposed to affect the corresponding indicators of bone tissue, the variables monitored (ash, calcium, phosphorus and magnesium) were determined in the fat-free dry matter (Table 5), all of them showing relatively higher levels, as compared to those in the original dry matter (Table 5). However, the trends found in the original dry matter (Table 3) were the same, i.e. the lower levels of ash, $\mathrm{Ca}$, and $\mathrm{P}$ in the experimental group except for $\mathrm{Ca}$ in male chickens, in both kinds of bones.

Table 4. Content of fat in bone tissues $(\mathrm{g})$

\begin{tabular}{|c|c|c|c|c|c|c|c|c|}
\hline Group & \multicolumn{4}{|c|}{ Female chickens $(\mathrm{n}=30)$} & \multicolumn{4}{c|}{ Male chickens $(\mathrm{n}=30)$} \\
\hline $\begin{array}{c}\text { C } \\
\text { Fat }\end{array}$ & Femur & Index $\%$ & Tibiotarsus & Index \% & Femur & Index \% & Tibiotarsus & Index \% \\
$17.4 \pm 8.44$ & 100 & $17.3 \pm 9.68$ & 100 & $17.7 \pm 6.38$ & 100 & $17.1 \pm 6.53$ & 100 \\
\hline E & & & & & & & & \\
Fat & $20.8 \pm 9.68$ & 119.5 & $21.0 \pm 9.12$ & 121.3 & $21.6 \pm 10.6$ & 122.0 & $21.6 \pm 10.8$ & 126.3 \\
\hline
\end{tabular}

Table 5. Levels of ash, Ca, P, and Mg in Groups C and $\mathrm{E}$ in fat-free dry matter $(\mathrm{g})$

\begin{tabular}{|c|c|c|c|c|c|c|c|c|}
\hline \multirow{3}{*}{$\frac{\text { Group }}{\mathrm{C}}$} & \multicolumn{4}{|c|}{ Female chickens } & \multicolumn{4}{|c|}{ Male chickens } \\
\hline & $(\mathrm{n}=30)$ & & $(\mathrm{n}=30)$ & & $(\mathrm{n}=30)$ & & $(\mathrm{n}=30)$ & \\
\hline & Femur & Index \% & Tibiotarsus & Index \% & Femur & Index \% & Tibiotarsus & Index \% \\
\hline Ash & $543.7 \pm 13.9$ & 100 & $551.8 \pm 9.61$ & 100 & $540.3 \pm 9.27$ & 100 & $542.0 \pm 13.4$ & 100 \\
\hline $\mathrm{Ca}$ & $209.9 \pm 6.49$ & 38.6 & $219.0 \pm 7.10$ & 39.7 & $202.0 \pm 8.32$ & 37.4 & $199.4 \pm 11.6$ & 36.8 \\
\hline $\mathrm{P}$ & $105.6 \pm 8.35$ & 19.4 & $105.2 \pm 4.89$ & 19.1 & $92.2 \pm 5.52$ & 17.1 & $94.0 \pm 6.04$ & 17.3 \\
\hline $\mathrm{Mg}$ & $2.40 \pm 0.24$ & 0.44 & $2.47 \pm 0.25$ & 0.45 & $2.36 \pm 0.23$ & 0.44 & $2.33 \pm 0.22$ & 0.43 \\
\hline $\mathrm{E}$ & $(\mathrm{n}=30)$ & & $(\mathrm{n}=30)$ & & $(\mathrm{n}=30)$ & & $(\mathrm{n}=30)$ & \\
\hline Ash & $529.4 \pm 10.7$ & 100 & $538.8 \pm 11.2$ & 100 & $529.6 \pm 14.5$ & 100 & $545.7 \pm 10.4$ & 100 \\
\hline $\mathrm{Ca}$ & $201.4 \pm 11.3$ & 38.0 & $202.4 \pm 10.8$ & 37.6 & $203.3 \pm 8.91$ & 37.7 & $205.3 \pm 8.11$ & 37.6 \\
\hline $\mathrm{P}$ & $97.7 \pm 5.76$ & 18.5 & $86.8 \pm 5.66$ & 16.1 & $80.8 \pm 5.90$ & 15.3 & $92.2 \pm 4.54$ & 16.9 \\
\hline $\mathrm{Mg}$ & $2.60 \pm 0.22$ & 0.49 & $2.48 \pm 0.22$ & 0.46 & $2.59 \pm 024$ & 0.49 & $2.33 \pm 0.21$ & 0.43 \\
\hline
\end{tabular}

Table 6 provides an overview of the monitored values in the absolute dry matter. Even in this presentation of the results, the trends in individual values were maintained and did not practically differ from the values found in the fat-free dry matter.

\section{Discussion}

The application of clinoptilolite $(0.5 ; 1.5$ and $2.5 \%$ of the commercial additive ZeoFeed) in feed mixtures designed for chickens in the experimental group was reflected positively in performance parameters, which is in good agreement with the findings made by the above-mentioned authors. Male and female chickens in the experimental group showed higher weights from Day 20 or Day 30 of the chickens' age, respectively. The differences on Day 30 were significant $(P \leq 0.05)$ and the weight of experimental chickens at the end of the experiment was significantly higher $(P \leq 0.01)$. The improved performance is likely to be associated with the improved utilization of nutrients (Olver 1997) and detoxifying effects of zeolites (Harvey et al. 1993; Skalická and Makoová 1999; Skalická et al. 2000; Parlat et al. 1999; Ortatatli and Oquz 2001; Rizzi at al. 2003), which has been documented repeatedly. The efficacy can be explained by slower passage of pre-digested food through the intestine which leads to the increased utilization of nutrients from the feeding dose, particularly 
Table 6. Levels of ash, Ca, P, and Mg in C and E groups, per absolute dry matter (g)

\begin{tabular}{|c|c|c|c|c|c|c|c|c|}
\hline Group & \multicolumn{4}{|c|}{ Female chickens } & \multicolumn{4}{|c|}{ Male chickens } \\
\hline \multirow[t]{2}{*}{$\mathrm{C}$} & $(\mathrm{n}=30)$ & & $(\mathrm{n}=30)$ & & $(\mathrm{n}=30)$ & & $(\mathrm{n}=30)$ & \\
\hline & Femur & Index \% & Tibiotarsus & Index $\%$ & Femur & Index \% & Tibiotarsus & Index $\%$ \\
\hline Ash & $529.8 \pm 13.6$ & 100 & $541.1 \pm 10.7$ & 100 & $533.3 \pm 8.82$ & 100 & $534.9 \pm 13.9$ & 100 \\
\hline $\mathrm{Ca}$ & $205.9 \pm 6.75$ & 38.9 & $214.8 \pm 7.53$ & 39.7 & $199.4 \pm 8.06$ & 37.4 & $196.8 \pm 11.8$ & 36.8 \\
\hline $\mathrm{P}$ & $103.6 \pm 8.30$ & 19.6 & $103.2 \pm 5.0$ & 19.1 & $90.8 \pm 5.12$ & 17.0 & $92.7 \pm 6.14$ & 17.3 \\
\hline $\mathrm{Mg}$ & $2.35 \pm 0.24$ & 0.44 & $2.43 \pm 0.24$ & 0.45 & $2.33 \pm 0.22$ & 0.44 & $2.30 \pm 0.22$ & 0.43 \\
\hline$E$ & $(\mathrm{n}=30)$ & & $(\mathrm{n}=30)$ & & $(\mathrm{n}=30)$ & & $(\mathrm{n}=30)$ & \\
\hline Ash & $517.2 \pm 11.7$ & 100 & $526.2 \pm 11.4$ & 100 & $518.2 \pm 15.1$ & 100 & $532.6 \pm 11.4$ & 100 \\
\hline $\mathrm{Ca}$ & $197.0 \pm 11.0$ & 38.1 & $197.7 \pm 10.8$ & 37.6 & $198.4 \pm 9.05$ & 38.3 & $196.8 \pm 7.83$ & 37.0 \\
\hline $\mathrm{P}$ & $95.5 \pm 5.85$ & 18.5 & $84.8 \pm 5.54$ & 16.1 & $78.9 \pm 5.84$ & 15.2 & $90.0 \pm 4.41$ & 16.9 \\
\hline $\mathrm{Mg}$ & $2.54 \pm 0.21$ & 0.49 & $2.42 \pm 0.21$ & 0.46 & $2.52 \pm 0.24$ & 0.49 & $2.28 \pm 0.21$ & 0.43 \\
\hline
\end{tabular}

nitrogen (Mumpton and Fishman 1977; Meisinger et al. 2001; Melenova et al. 2003). Similarly, the adsorption of mycotoxins as common components of feed mixtures could also be reflected in the performance indicators and the health condition of broiler chickens (Rosa et al. 2001; Papaioannou et al. 2005). Zeolites also participate in the elimination of heavy metals (Tepe et al. 2004) and radioactive elements, and play an important role in the repair of the metabolic defects of the skeleton (Papaioannou et al. 2005).

The components received with the feed and harmful substances formed by intestinal microorganisms (e.g. $\mathrm{NH}_{4}$, enterotoxins) undergo adsorption and elimination which prevents their penetration into the blood circulation, thus decreasing the load of the liver with toxic substances. The energy necessary for detoxification is used to increase performance. Another favourable aspect of zeolites is that they can contribute to the metabolic utilization of nitrogen and decrease its excretion in faeces. Apart from the beneficial effect of zeolites on performance indicators in animals, the supplementation of diets with zeolites helps to prevent some diseases and improves the general health of animals (Papaioannou et al. 2005).

The effect of the addition of zeolite on performance indicators and bone metabolism indicators in broiler chickens was studied by Leach et al. (1990) who reported weight gains in broilers and the enhanced deposition of calcium in bones in the case of deficient or boundary level of calcium, thus relieving the symptoms of rickets. The level of ash in bones was also higher. The results of our experiment showed that the level of ash in the dry matter of bone tissue varied in a range of $53.0-54.1 \%$ in the control group and in a range of $51.7-53.2 \%$ in the experimental group which was non-significantly lower. The amount of ash in the tibiotarsus was higher than that in the femur in both groups, regardless of sex. The levels of calcium in the diets of chickens corresponded to the respective demand. In comparison with the results reported by Leach et al. (1990), the levels of $\mathrm{Ca}$ and $\mathrm{P}$ in dry matter in the experimental group were lower than those in the control group. The only exception was the level of $\mathrm{Ca}$ in the tibiotarsus in male chickens. The level of $\mathrm{Ca}$ in ash was about $20 \%$ in the control group, being lower in male chickens, while in the experimental group it was below $20 \%$. Similar results were found in the case of phosphorus where the levels of phosphorus in the control group varied in a range of $9.06-10.4 \%$, the lower level of phosphorus was found in the experimental group, ranging between 7.92 and $9.55 \%$. The levels of magnesium between both groups and sexes did not differ.

Venalainen et al. (2006) reported that the level of ash, calcium and phosphorus in the tibiotarsus in broilers receiving a diet with a lower content of $\mathrm{ME}(11.0 \mathrm{MJ} / \mathrm{kg})$ was higher 
than that in broilers receiving a diet with a higher content of $\mathrm{ME}(12.0 \mathrm{MJ} / \mathrm{kg})$. The levels of ash, calcium, and phosphorus increased, depending on the content of usable phosphorus in a diet. The feed mixtures used in our experiment (BR1, BR2, BR3) contained significantly more ME, as compared to those reported by Venalainen et al. (2006), ranging from 12.6 to $13.5 \mathrm{MJ} / \mathrm{kg}$. One may assume that the reason for different results lies in the level of ash, calcium, and phosphorus in bones.

Grosicki and Kowalski (2003), Grosicki et al. (2004), and Grosicki and Rachubik (2005) reported the slightly lowered absorption of calcium and selenium in organs and increased absorption of iron after the 28-day administration of a diet supplemented with $2 \%$ of bentonite in rats, which is in good agreement with our results with respect to calcium.

As reported in literature (Papaioannou et al. 2005), zeolites received by the body participate in a number of biochemical processes through ion exchange, adsorption, and catalysis. Further investigations will allow a wider use of zeolites in the prevention and therapy of some of the diseases of farm animals.

\section{Aplikace klinoptilolitu během výkrmu brojlerových kuřat a jeho vliv na intenzitu růstu a ukazatele kostního metabolismu}

Byly sledovány intenzita růstu a ukazatele kostního metabolismu při podávání klinoptilolitu v krmivu brojlerových kuřat. Jednodenní brojlerová kuřata ROSS 308 byla rozdělena do kontrolní (C) a pokusné (E) skupiny; v každé skupině bylo 100 kohoutků a 100 slepiček. Do 10. dne věku přijímala kuřata kompletní krmnou směs BR1, následně do 30 . dne věku BR2 a do konce výkrmu (40. dne věku) krmnou směs BR3. Krmné směsi pokusné skupiny obsahovaly $0,5 \%$ (BR1), 1,5\% (BR2) a 2,5\% (BR3) klinoptilolitu (komerční aditivum ZeoFeed), náhradou za stejný podíl pšenice. Krmné směsi a pitná voda byly podávány ad libitum. Zivá hmotnost brojlerových kuřat skupiny C i E se v průběhu sledovaného období rovnoměrně zvyšovala. Na konci pokusu byla živá hmotnost u pokusných slepiček $(2416 \mathrm{~g})$ a kohoutků (2829 g) vyšší než u kontrolních slepiček (2345 g) a kohoutků (2694 g) o $3 \%$, resp. o $5 \%$. Významné rozdíly v živé hmotnosti mezi skupinami byly zaznamenány od 30. dne věku $(P \leq 0,05$ a $P \leq 0,01)$. Ve věku 40 dnů byla kuřata poražena a u femuru a tibiotarsu pravého běháku byl stanoven obsah sušiny, popele, vápníku, fosforu a hořčíku. Obsah popele v sušině se pohyboval u skupiny $\mathrm{C}$ v rozmezí od 53,0 \% do 54,1 \% a u skupiny $\mathrm{E}$ od $51,7 \%$ do $53,2 \%$. U skupiny E byla hladina Ca a $\mathrm{P}$ v sušině nižší než u skupiny $\mathrm{C}$, s výjimkou hodnot $\mathrm{Ca}$ a $\mathrm{P}$ v tibiotarsu kohoutků. U obou skupin, bez ohledu na pohlaví, byl podíl popele vyšší v tibiotarsu než ve femuru. Vzhledem k vyššímu obsahu tuku v kostech pokusné skupiny (slepičky o 19,5\% u femuru a 21,3\% u tibiotarsu, kohoutci o $22,0 \%$ u femuru a $26,3 \%$ u tibiotarsu), a možnému ovlivnění získaných hodnot obsahem tuku v kostní tkáni, byly popel, vápník, fosfor a hořčík stanoveny v tukuprosté sušině. Trendy zjištěné v původní sušině zůstaly zachovány, tzn. nižší podíl popele, Ca a $\mathrm{P}$ u pokusné skupiny, s výjimkou $\mathrm{Ca}$ u kohoutků v obou kostech. V tukuprosté sušině byly oproti původní sušině hodnoty relativně vyšší. Výsledky práce ukázaly, že obohacení diety klinoptilolitem v množství do 2,5\% nemělo negativní vliv na ukazatele užitkovosti a kostního metabolismu brojlerových kuřat ve výkrmu. Je možné jej tedy využít jako vhodného doplňku do diety brojlerů pro zlepšení využití živin z krmiva, pro pozitivní vliv na mechanismus trávení a eliminaci polutantů v souvislosti s řešením otázek spojených s bezpečností potravin.

\section{Acknowledgement}

This research was conducted in the frameworks of the Research Plan of the Czech Republic Ministry of Education, Youth, and Physical Training No. MSM6215712402 "Veterinary Aspects of Food Safety and Quality". 


\section{References}

ANONYMOUS 2001: AOAC - Association of Official Analytical Chemists International; Horwitz W. (Ed.): Official Methods of Analysis. $17^{\text {th }}$ ed. AOAC Inc., Arlington, USA

AMON M, DOBEIC M, SNEATH RW, PHILLIPS VR, MISSELBROOK TH, PAIN BF 1997: A farm-scale study on the use of clinoptilolite zeolite and De-Odorase ${ }^{\circledR}$ for reducing odour and ammonia emissions from broiler houses. Bioresour Technol 61: 229-237

BALLARD R, EDWARDS HM 1988: Effects of dietary zeolite and vitamin-A on tibial dyschondroplasia in chickens. Poult Sci 67: 113-119

EDWARDS HM 1988: Effect of dietary calcium, phosphorus, chloride, and zeolite on the development of tibial dyschondroplasia. Poult Sci 67: 1436-1446

EDWARDS HM 1984: Studies on the etiology of tibial dyschondroplasia in chickens. J Nutr 114: 1001-1013

GROSICKI A, KOWALSKI B 2003: Influence of bentonite on trace element kinetics in rats. I. Iron. Bull Vet Inst Puławy 47: 555-558

GROSICKI A, KOWALSKI B, BIK D 2004: Influence of bentonite on trace element kinetics in rats. II. Calcium. Bull Vet Inst Puławy 48: 337-340

GROSICKI A, RACHUBIK J 2005: Influence of bentonite on trace element kinetics in rats. III. Selenium. Bull Vet Inst Puławy 49: 121-123

HARVEY RB, KUBENA LF, ELISSALDE MH, PHILLIPS TD 1993: Efficacy of zeolitic ore compounds on the toxicity of aflatoxin to growing broiler chickens. Avian Dis 37: 67-73

LEDWABA MF, ROBERSON KD 2003: Effectiveness of twenty-five-hydroxycholecalciferol in the prevention of tibial dyschondroplasia in Ross cockerels depends on dietary calcium level. Poult Sci 82: 1769-1777

LEACH RM, HEINRICHS S, BURDETTE J 1990: Broiler chicks fed low calcium diets. 1. Influence of zeolite on growth rate and parameters of bone metabolism. Poult Sci 69: 1539-1543

MEISINGER JJ, LEFCOURT AM, VAN KESSEL JA, WILKERSON V 2001: Managing ammonia emissions from dairy cows by amending slurry with alum or zeolite or by diet modification. Scientific World Journal 27 : 860-865

MELENOVÁ L, CIAHOTNÝ K, JIRGLOVÁ H, KUSÁ H, RŮŽEK P 2003: Removal of ammonia from waste gases by adsorption on zeolites and their utilization in agriculture (In Czech). Chem Listy 97: 562-568

MUMPTON FA 1999: La roca magica: Uses of natural zeolites in agriculture and industry. Proc Natl Acad Sci USA 96: 3463-3470

MUMPTON FA, FISHMAN PH 1977: The application of natural zeolites in animal science and aquaculture. J Anim Sci 45: 1188-1203

OLVER MD 1997: Effect of feeding clinoptilolite (zeolite) on the performance of three strains of laying hens. Br Poult Sci 38: 220-222

ORTATATLI M, OGUZ H 2001: Ameliorative effects of dietary clinoptilolite on pathological changes in broiler chickens during aflatoxicosis. Res Vet Sci 71: 59-66

PAPAIOANNOU DS, KATSOULOS PD, PANOUSIS N, KARATZIAS H 2005: The role of natural and synthetic zeolites as feed additives on the prevention and/or the treatment of certain farm animal diseases: A review. Microporous Mesoporous Mat 84: 161-170

PAPAIOANNOU DS, KYRIAKIS CS, PAPASTERIADIS A, ROUMBIES N, YANNAKOPOULOS A, ALEXOPOULOS C 2002: A field study on the effect of in-feed inclusion of a natural zeolite (clinoptilolite) on health status and performance of sows/gilts and their litters. Res Vet Sci 72: 51-59

PAPAIOANNOU DS, KYRIAKIS CS, ALEXOPOULOS C, TZIKA ED, POLIZOPOULOU ZS, KYRIAKIS SC 2004: A field study on the effect of dietary use of a clinoptilolite-rich tuff, alone or in combination with certain antimicrobials, on the health status and performance of weaned, growing and finishing pigs. Res Vet Sci 76: 19-29

PARLAT SS, YILDIZ AO, OGUZ H 1999: Effect of clinoptilolite on performance of Japanese quail (Coturnix coturnix japonica) during experimental aflatoxicosis. Br Poult Sci 40: 495-500

RIZZI L, SIMIOLI M, RONCADA P, ZAGHINI A 2003: Aflatoxin B1 and clinoptilolite in feed for laying hens: Effects on egg quality, mycotoxin residues in livers, and hepatic mixed-function oxygenase activities. J Food Prot 66: 860-865

ROSA CAR, MIAZZO R, MAGNOLI C, SALVANO M, CHIACCHIERA SM, FERRERO S, SAENZ M, CARVALHO ECQ, DALCERO A 2001: Evaluation of the efficacy of bentonite from the south of Argentina to ameliorate the toxic effects of aflatoxin in broilers. Poult Sci 80: 139-144

SKALICKÁ M, MAKOOVÁ Z, KORÉNEKOVÁ B 2000: The influence of aflatoxin B-1 on activity of alkaline phosphatase and body weight of broiler chicks. Trace Elem Electrolytes 17: 142-146

SKALICKÁ M, MAKOOVÁ Z 1999: Elimination of aflatoxin B-1 in broiler chicks by clinoptilolite. Bull Vet Inst Puławy 43: 211-219

SOUTHERN LL, WARD TL, BIDNER TD, HEBERT LG 1994: Effect of sodium bentonite or hydrated sodiumcalcium aluminosilicate on growth performance and tibia mineral concentrations in broiler chicks fed nutrientdeficient diets. Poult Sci 73: 848-854 
TEPE Y, AKYURT I, CIMINLI C, MUTLU E, ÇALIŞKAN M 2004: Protective effect of clinoptilolite on lead toxicity in common carp Cyprinus carpio. Fresenius Environ Bull 13: 639-642

VENALAINEN E, VALAJA J, JALAVA T 2006: Effects of dietary metabolisable energy, calcium and phosphorus on bone mineralisation, leg weakness and performance of broiler chickens. Br Poult Sci 47: 301-310

WALDENSTEDT L 2006: Nutritional factors of importance for optimal leg health in broilers: A review. Anim Feed Sci Technol 126: 291-307

WATKINS KL, SOUTHERN LL 1991: Effect of dietary sodium zeolite A and graded levels of calcium on growth, plasma, and tibia characteristics of chicks. Poult Sci 70: 2295-2303 
